Article

\title{
The Stakeholders' Perspective within the B Corp Certification for a Circular Approach
}

\author{
Stefano Poponi ${ }^{1, *(\mathbb{D}}$, Andrea Colantoni ${ }^{2}$ (D) Sirio R.S. Cividino ${ }^{3}$ and Enrico Maria Mosconi ${ }^{4}(\mathbb{C}$ \\ 1 Faculty of Economics, Niccolò Cusano University, Via Don Carlo Gnocchi 3, I-00166 Rome, Italy \\ 2 Department of Agricultural and Forestry Sciences (DAFNE), Tuscia University, Via S. Camillo De Lellis, \\ 01100 Viterbo, Italy; colantoni@unitus.it \\ 3 Department of Agriculture, University of Udine, Via delle Scienze 206, I-33100 Udine, Italy; \\ agricolturasicura@gmail.com \\ 4 Department of Economics Engineering, Society and Business Organization, Tuscia University, \\ Via del Paradiso 47, I-01100 Viterbo, Italy; enrico.mosconi@unitus.it \\ * Correspondence: stefano.poponi@unicusano.it
}

Received: 30 January 2019; Accepted: 9 March 2019; Published: 15 March 2019

\begin{abstract}
A circular economy has been gaining momentum as the most innovative approach in business. Its proposed model, based on sustainability and new product-driven differentiated strategies of production and organizational exchange, has brought to light the need to better understand the relevance of stakeholders as a critical factor in the creation of new added value in business management. The primary purpose of this paper is to investigate how the B-Corp Certification System could contribute to a process of awareness raising in business organizations. It also focuses on the stakeholders' commitment, within the framework of circular economy principles, and demonstrates that those companies who are adopting the certification concerning "recycling service and waste management" strongly contribute to the development in the direction of the circular economy. The analysis of the case studies shows two possible scenarios describing the circular approach in business and the different roles of stakeholders in the activation of such a virtuous path. "Social recycling" considers the key role of social participation and contribution in circular-economy related activities of primary and secondary stakeholders, and "highly regenerative recycling" aims to involve qualified stakeholders to start inter-organizational symbioses within the circular process of waste recycling. Key factors, such as industrial symbiosis, tax benefits, financial incentives, legislative harmonization, and the consumers' behavior, represent the tenets of the circular economy model An awareness-raising perspective and the capacity on the part of companies to understand the relevance of stakeholders and the way to transform their role into the most effective lever to reinforce competitiveness is therefore necessary. Accordingly, the whole system of Benefit Corporation certification could boost business towards new business models involving stakeholders in several directions.
\end{abstract}

Keywords: B Corp certification; circular economy; sustainability; multi-stakeholder perspective

\section{Introduction}

The traditional levers of competitiveness that have led company strategies to focus only on economic priorities are now moving towards a more comprehensive approach, including a wider sustainability field. Thus, environmental and social goals have to be integrated into the decision-making processes [1]. Along this line, the new business model, which is more socially inclusive and has the capability to interpret the stakeholders' relevance, is essential to generate enterprise added-value. According to the literature, the study of how the specific economic activities 
contribute or influence the environment [2] includes the analysis of specific elements to increase the capacity of the organizations to better understand the mechanism of the new model based on the involvement and commitment of the Stakeholders [3].

Firms and organizations, in order to obtain a comprehensive understanding of the new multiple business challenges, are committed to researching an innovative combination of methods, where combined synergies of the different approaches are the rule. Consequently, new management schemes are formulated to maintain the programmed day to day operations in top performances resource management. These schemes show the attention devoted to increasing the multi-dimensional-environment management in the light of an "overall" resource efficiency perspective.

Most important, though, the enlargement of the management system's scope in a multicultural-stakeholder context should not affect the central role of consumers, which is the baseline of the added-value chain.

From an operational point of view, current managerial techniques have already tried to take into account the stakeholder salience [4], identifying necessary resources and capabilities for the entrepreneurial scope. From a managerial point of view, in addition to the different views regarding salience attributes (credibility, transparency, etc.), key enabling factors, such as legislative harmonization, Industrial Symbiosis, Incentive, and consumers behavior, provides an effective path to move towards a Circular Management model [5].

In this sense, the new development paradigm proposed by a circular economy is based on three rationale pillars: the idea of the reuse of waste as a resource, on the potentials of recycling activities (for the exploitation of waste as raw and secondary materials), and the need to rethink the life-cycle of goods [6,7]. It allows combining different approaches to convey a change, using collaborative networks and support tools and a top-down model [8].

The European Union has a long-standing commitment towards sustainability, environmental, safety, and health issues and has repeatedly attempted to convey, directly and indirectly, through its programs [3], the transition towards a new development model and is able to start the competitive spiral of change. An example of this commitment is the adoption of the Circular Economy policies by the European Commission (EC) in the "Circular Economy Package" that, in 2014, included "Towards a circular economy: a zero waste program for Europe" and, in 2015, the Communication "Closing the loop-An EU action plan for the circular economy".

In this new approach to the economy, besides the top-down, a bottom-up approach arises and contributes to its model evolution. In this regard, a new generation of tools has been developed, combining management techniques such as Collaborative business models, Product design, Supply chain, Information and communication technology (ICT) [8], and the Product Service System (PSS) business model [9] within the voluntary certification systems as, for example, the adoption of an environmental management system [10].

For such reason, B Corp certification can be included in the bottom-up approach. This is a voluntary system promoting business sensitivity towards ethical, environmental, and customer satisfaction issues, involving all stakeholders of the process (workers, community, environment) and is able to propose an alternative governance model [11].

In these new business models, the idea of social responsibility as a form of self-regulation is strengthened [11,12]. Through a voluntary certification scheme, these companies aim to rebalance their mission and business activities-affirming principles of social responsibility, therefore simultaneously achieving both their profit and non-profit objectives.

This approach finds its full application for the management system with a new B-Corp certification frame, procured by B Lab. a non-profit entity conceived with the purpose to promote the inception of the Certified B Corps. In addition, it supports the creation of a community of companies interested in promoting social and environmental concerns, encouraging the development of an adequate legal framework for a benefit business, and conceives an innovative evaluation standard, the Global Impact 
Investing Rating System (B Lab. n.d.). By means of appropriate indicators, this standard aims at measuring the impact of the benefits of companies and their orientation towards value creation. The system of ranking qualifies enterprises with a score of over 80 out of 200 total points. Moreover, it is assigned, for each impact area, a prize to the the top-performing Certified B Corps. This is a supportive tool of self-evaluation that aims to asses the level capacity to reach the "social objectives" in the pre-certification stage.

The common denominator between the circular economy approach and the use of B Corp Certification presents a key question: how can we raise awareness and increase capacity, in firms and organizations, for stakeholders' to perceive relevance, and how can we turn them to be effective levers of strength competitiveness? The circularity approach and the B-Corp work in the same direction, however not everything about these models can be applied to each other [13].

In light of the above considerations, the main objective of the present paper is to identify and discuss the potential of circular economy and B-Corp certifications from a multi-stakeholders' perspective. In particular, a compared multiple analysis of case studies is offered and the contribution of B-Corp certification is presented as a key factor in the implementation of structural change in business.

\section{Circular Economy Principles and Key Requirements within the B-Corp Certification Process from a Common Viewpoint}

The awareness of the different stakeholder categories concerning the volatility and uncertainty, as well as the availability of the natural resources, is the key pressure points that pushed the adoption of the circularity concept to be an opportunity for the evolution of the business model and also to go beyond the "sustainability" vision.

The baseline of this concept is the development of the economic loop mechanism [10,14-17] in which waste becomes the raw materials of the future. It consists of important pillars including Industrial symbiosis and ecology, regenerative design, performance economy, and cradle to cradle subject [10,16,18-22].

The entailment of their systematic adoption into the business processes and the introduction of sustainable development principles [23] have facilitated the switch from the so-called brown economy [24] to the green economy.

The brown economy is based on the exploitation of resources and the economic capital, wherein a high consumption of resources pushes the linear approach and short life cycle of products, whereas on the contrary, the introduction of new models that promote recovery/recycling and discourage landfilling are providing further impetus on new levers for growth.

A circular economy enables, in fact, the development of a brand new paradigm where the concept of the linear economy (from raw material to waste [25]) is overcome by the new model of the circular economy [26,27].

The Report Towards the Circular Economy defined circular economy as "an industrial system that is restorative or regenerative by intention and design" [27]. This definition has made it possible to match two long-established concepts: needs to reduce the amount of natural and energy resources used in the creation of a product or service, and, at the same time, increasing the possibilities of the same resources being reused at the end of a product life cycle.

Furthermore, different key factors emerge as enablers and transition facilitators within this context. In accordance with a previous study [5], we will consider in depth the main key factors that enable the CE process, as follows: (a) Product redesign, (b) Process redesign, (c) Business model innovation, (d) Waste reduction or reuse, (e) Regulation, (f) Potential cooperation, (g) Fiscal and financial stimuli, and (h) Consumer behavior.

The adoption of new design patterns, considering the factor Product redesign (a), allows "short-term" recycling processes, while the combination of products and services will result in the development of new opportunities for the creation of added value. Several authors [28-30] focus 
on the need to intervene in the project of a product, redesigning the use of the product through the PSS approach, or developing new product concepts using Eco-design $[28,30]$.

Process redesign (b) can be an inventive and iterative process where new ideas on how to meet needs are converted to products and services [28]. Nevertheless, the production processes must address the problem of waste and energy consumption reduction, of the environmental impact, and the shift to renewable energy sources [31]. From this point of view, a valuable contribution can also be obtained from the integration of specific levels of service in the design and development of products and services in compliance with the logic of the product service system [32]. According to this perspective, companies put on the market a product/service mix aimed at meeting a specific customer need, while safeguarding the sustainability of production and product/service supply [33]. Following this approach, the concepts of products that can be disassembled, and whose components can be separated and reconfigured, are crucial, along with an approach to sterilization and dematerialization of products and services.

Business model innovation (c) can be extended to a system level rather than just to individual companies and can help to generate huge savings and economic benefits for the entire community. For Schulte [34], the new business models are consistent with the circular economy and create an advantage for the economy and the environment, in particular " [... ] Business model is a part of the transition toward circular economy [ ... ] they must be developed to support the transition" [35]. "Adopting more circular business models would bring significant benefits, including improved innovation across the economy" [36], which is not delivered by conventional linear chains [37].

Waste Reduction or reuse (d) generates obvious advantages connected with the lower utilization of raw materials, the reuse, the production of goods with longer life cycles, and reuse and recycling of materials and components [38,39], or also activating a second cycle life, regenerating the functionality of the product. Furthermore, by placing waste reduction and reuse at the top of the hierarchy, management strategies that prioritize conserving embedded energy and materials are shown to be favored [40].

Seviné-Itoiz et al. [41] highlight, for the achievement of the CE, the importance of a systemic change in the use and recovery of resources, and the adoption of different strategies to adapt the sector to different flows of materials [42] and quality, including the activities into account import and export. "Additional value can be generated through recycling and reuse of materials and products", therefore R\&D supports the efficiency of materials [43].

About Regulation (e), Riding et al. [44] emphasize the inadequacy of this factor, seen as a barrier and often as being inadequate to support the change, in the same way as "laxity of enforcement of environmental regulations" [42]. At the same time, it is necessary to adopt a holistic view of waste and the need to apply appropriate regulation ... "The prior method on pushing circular economy development is to execute compulsory regulation" [45]. Likewise, a different regulation at the European level generates uncertainty, which is also financial, for landfill operators [46].

Potential Cooperation (f) is the basis for the successful strategies of the circular economy $[47,48]$ or the activation of industrial symbiosis [49-53]. Nevertheless, industrial symbiosis requires organizations to change their functions and increase competitiveness in a perspective of global integration concerning social, environmental, and economic characteristics. Many studies [51,54-57] focus their studies on the factors that affect the performance of productive contexts, facilitating the adoption of a radical change in the traditional industrial paradigm.

Another factor enabling the circular economy is consumer behavior (h). It is necessary to stimulate a change in consumption habits, which must be led by a general change in consumer and producer culture $[58,59]$, however the consumer's awareness of the circular economy might not directly translate into a willingness to pay for healthier products [60]. a real contribution to the circularity of the materials requires a different design approach in products and services. In specific, for products, this would include a consideration of their recycling or reuse potential at the design stage [32,59], 
while for services, this would entail providing them through a mix of interrelated elements that can easily be disassembled and re-assembled into new forms to supply new and innovative services [61].

The above factors are used in Section 4 (results and discussion) to discuss how the B Corp certification (in particular, the requirements described in each area of Section 5) of the selected company activates the circular economy pathway in multiple stakeholder perspectives.

In regards to the dissemination of circular economy, it supposes the adoption of business models aimed to stimulate policymaking to support business development and new innovative business management, which will eventually enable environmental sustainability oriented behaviors [34], more efficient use of resources, and the respect of ethical, social, and environmental values. Benefit Corporations are companies pursuing these objectives with the twofold aim of reconciling business performances (economic and financial) with ethical behavior. In these new business models, the idea of social responsibility as a form of self-regulation is strengthened [11,12]. Through a voluntary certification scheme, these companies aim to rebalance their mission and business activities-affirming principles of social responsibility, therefore simultaneously achieving both their profit and non-profit objectives.

This approach finds its full application in the management system within a new B-Corp certification frame, procured by B Lab. It is a non-profit entity conceived with the purpose of promoting many key points: the inception of the Certified B Corps, the creation of a strong relationship with the community of companies, and the development of an adequate legal framework for benefit business. Furthermore, it considers an innovative evaluation standard, the Global Impact Investing Rating System [62]. Utilizing indicators, this standard measures the impact of benefits companies and the orientation towards value creation, using in its pre-certification stage, a tool of self-evaluation that is aimed to assess both social and environmental-related performances.

This framework considers several areas: governance, workers, community, environment, and customers and assesses the impact evaluation of the Impact Business Models and Metrics.

The indicators system aims to clearly identify, through the "Governance" of the impact area, the mission and traceability of environmental and social performances, the responsibility, the monitoring, and the involvement of the stakeholders. a code of conduct associated with internal financial controls is aimed at preventing and managing complaints or corruption and transparent funding, and the communication with clients and workers is also provided.

The area "Worker" incorporates the equity of the performances and refers, in particular, to the adequacy of salaries and possible career progression within the company. Skills and a company's abilities are essential elements to keep a high formation level of the company's staff, therefore ensuring the transferability of competencies/knowledge and the identification of the degree of participation of the workers. This latter aspect is also evaluated within the internal business decisional process. Moreover, it is also associated with other aspects such as sustainable working conditions, compatible with their lifestyle, and the respect of the values of working life and of work conditions in general. The area also considers the workers' degree of trust in the company and its managers and the system of harmonized guarantees for the worker in cases of occupational diseases.

External stakeholders are included in the "Community" Area, in accordance with the principle of integration of suppliers (central in the general approach to quality) and the constant monitoring of the satisfaction of expectations and the involvement of the local community. The presence of codes of conduct aims to ensure the safety of workers and of the working environment. Equally, the respect and support of the development of local economies are considered. The promotion of social wellbeing within the company, by means of inclusion policies and social engagement, is considered so that societal values are tailored to meet social needs, and the practices which could be transferred and promoted outside the company, also including services to the community, donations, and charity activities, are also considered. Such an area aims at monitoring how the company products are designed to meet social needs. The certification, in this case, considers further aspects related to access 
to basic services, such as health, education, or equal opportunities, the arts, and the increase of capital invested in such activities.

The extension of the corporate policies to the "Environment", and also the commitment towards the enhancement of its environmental performances, represents a priority within this area. Two factors are considered here: an input factor (i.e., power, water, and raw materials), with a need of constant and continuous assessment of the reduction of impact and consumption; and an output factor, to consider the effects produced by emissions and the different types of waste produced, transportation, and distribution. Such factors need simultaneously continuous monitoring to improve the environmental-related performances (pursued by the many systems of certifications, e.g., ISO 14000; EMS, BSI 8001) considering the efforts to reduce the impact on the environment. At a more general level, it considers the policies and all the actions aimed at producing a positive effect on the reduction of the impact. In particular, they consider the way that products and services are designed to solve an environment-related issue, pushing towards renewability and conservation, reduction of waste, and the promotion of the preservation of nature. They also consider aspects related to the environmental culture and, more precisely, to promote environmental education.

Through the area "Customer", the certification intends to evaluate the impact of the policies and, consequently, the actions that were taken by the company, and how this affects their customers. In particular, in this section, the company looks in more depth at the relationship with its community, evaluating the relations with suppliers, diversity, and their involvement in the local community. Finally, the ability to promote public benefit through different aspects, that is the selling of their products, the social services provision, or the capability to solve social problems, is evaluated.

\section{Methods}

For the study, we consider the key factors that emerge as enablers and transition facilitators within the context of the circular economy. In particular, in accordance with a previous study [5], we discuss how the requirements of B Corp certification activate the circular economy pathway in multiple stakeholder perspectives. The factors considered are as follows:

(a) Product redesign;

(b) Process redesign;

(c) Business model innovation;

(d) Waste reduction or reuse;

(e) Regulation;

(f) Potential cooperation;

(g) Fiscal and financial stimuli;

(h) Consumer behavior.

The methodological approach, to study the selected enterprises, is based on the study protocol of a descriptive case study defined by Yin $[63,64]$, while the analysis of the information about the certification was conducted by using documentary analysis [65].

Within the certification path, documentation is the fundamental aspect to be addressed for the success of the verification phase. Documentation makes it possible to achieve two goals: on one hand, it allows them to reach the requirements of the management system and, on the other hand, it supports self-assessment processes and audits (internal or external).

The documentary analysis study of the documentation [49] is the pillar to pick up concrete information about the commitment of entrepreneurs to reach achievable objectives (measurable). Another aspect to be considered is that the information in the documentation is subject to the same International standard. It implies an ample opportunity in terms of comparison of information among the certificated B Corp organizations.

The enterprises were selected through the B Corp platform, choosing "recycling service \& waste management" as a reference industry for analysis The research system has identified 10 enterprises 
working at an international level in this field. Companies that do not have an international profile have been excluded, having no documentation and/or an institutional website. The companies selected for the following multiple comparative analysis are: "All Green Recycling Inc.", "Surplus Service", "Bolder Industries", and "Homeboy Recycling".

For this purpose, we used the official documents released by the B Corp certification system, (annual report), including the documentation published by the organizations considered. Also, the research focused the attention to the monitoring activities of the services provided by the enterprises and to the effectiveness of the communication measures, such as social media and newspapers. The documents identify the formal referenced properties. Through conceptualization, we compiled a paper concept table identifying the factors defined above and those positively influencing a circular economy, either directly or indirectly of the stakeholder perspective.

All four authors separately analyzed the selected documents based on the proposed categorization. After the first phase, the authors processed the information iteratively to arrive at the discussion of a paper-concept table, excluding non-pertinent information. It consequently led to the identification of the contribution of stakeholders, the business implications, and the limitations in their progressive adoption of a circular economy approach.

The results obtained will represent the starting point for more in-depth investigations, which would allow the definition of the association between the implementation of a management system based on the B-Corp standard and the role of the stakeholders in the application of the circular economy. Previous studies complete our analysis [8-13].

\section{Results and Discussion}

The compared multiple analysis was conducted on four companies who were certified according to the standard B-Corp, which have an international profile and are traceable to the sector "Recycling services \& Waste Management". The sector itself is inclined to adopt the circularity approach. Thus, the research units were chosen herein to observe in depth the running of the elements of interdependence among the key factors to activate the circular process. This kind of analysis will allow the consideration of different kinds of inter-organizational cooperation activities put in place by the companies in the multi-stakeholder context. The data were provided by the study of the units of analysis and were based on the observation of secondary data, documents issued by the certifying body (annual reports, 2017) on the documentation available to companies.

The first analysis unit is the company "All Green Recycling Inc". It is a company that works in the field of the recovery of precious materials and metals coming from E-Waste. Specifically, it works in strategic sectors as well the military and healthcare sector in which it is essential to ensure the safe disposal of wastes, also in terms of secrecy of information (e.g., Military Hard disk).

The company's governance has a strong attitude to face the problem of sustainability. Specifically, it focuses its activities on the definition of certified and customized solutions. The analysis of the different specific activities draws attention to the need to become a reference point within this industry, creating a national footprint to serve the recycling industry. a strong internal policy integrates the secrecy of information inside, and the definition of tighter control systems also oversees the activities. Among the strategic activities within the social scope, a foundation promotes, at a corporate level, the education and training of disadvantaged and unemployed people, which is headed to a specific community that benefits from it. It provides training and employment opportunities to challenged workers and a system certified about woman-owned and woman-controlled business.

The second unit is the company "Surplus Service" which operates in the recycling and reuse of technological products. It offers specific solutions for the disposal and conversion of IT products. While focused on recycling activities, the company's governance includes the management of processes heavily oriented towards re-using the product with a clear objective to break down or postpone the substitutability of discarded goods. Thus, from an environmental point of view, there is strong attention 
on the different components of the supply chain by introducing a Sustainable Procurement Program, measures for energy reduction, gallons of water, and $\mathrm{CO}_{2}$.

In-kind donations and pro-bono services are provided with the precise scope to support training programs oriented towards a targeted community. Specific activities are put in place to help raise awareness of the consumers regarding sustainability issues, including events to promote domestic recycling.

The third unit is a company specializing in tire reuse, the "Bolder Industries". The core competence developed consists of sustainable alternative technology to carbon black (Bolder Black) that performs a significant increase of the environmental performance. The system allows giving specific attention to all aspects of the activities, of the entire process, in terms of reduction of water needed which has the effect of $\mathrm{CO}_{2}$ reduction. Supported by production standards and by obtaining environmental awards (e.g., Best B-Corp for the environment in 2017), the company has a high level of specialization in the field, which is stimulated by the need for the integration of qualified human-capital in the manufacturing processes. The activity of the community (or social participation) is not absolutely evident from the analysis, however is adequately demonstrated as the company is active in the diffusion/promotion of sustainability education and the reduction of their environmental impact.

The fourth unit, "Homeboy Recycling”, manages E-Waste's recovery activities (e.g., electronics, Televisions, Monitors, Audio Equipment, etc.), combining environmental sustainability with a social mission to re-employ people with criminal records.

The specific nature of its activities puts the company business into the health and safety policy class. The community is also stimulated by being involved in a wide range of dissemination activities of the results by means of press, social media, and public events. Positive information is provided by the company as to how, on average, "for every 75,000 lbs of electronic equipment collected, [the creation of new jobs] becomes economically viable". In this way, the participation of the whole community is stimulated towards a greater awareness of the importance of recycling and the possibility of generating new kinds of value for the whole community.

Table 1 shows, starting from the analysis of the areas of B Corp certification, the way the stand activates key factors in the circular economy.

Recycling represents the core business activity for all Units analyzed. From the analysis of the factors elaborated in Table 1, arises some important considerations.

Regarding the "process design" factor, its results are characterized by the ability to adapt to the offer of the potential supplier with a customized policy for product recovery. The activation of withdrawal protocols, as well as the treatment and management of wastes, are very advanced. This allows the Units to guarantee a high level for waste treatment. Furthermore, these processes are supported by a strict standard of certification to assure the reliability of the whole process. It is the case of Units 1, 3, and 4 that the selection of products is affected by the level of data security for the E-Waste. Therefore, the limits imposed on waste treatment affect the "process design", starting from the recovery to the sale of the final product. The "users", within the loop cycle, are the first recipients of the new processes' effects. Corporate policies condition them and are bound to legislative aspects.

The "Business model innovation" factor amplifies the opportunity offered by the circular economy.

In such a model, high innovation plays a key role in new reengineering thereof. This is the case of Unit 3, wherein specific application of a patented process made it possible to make changes for the tires recycling process in the direction of sustainable and innovative approaches. Alternatively, it is the case of Unit 2 that extends the useful life cycle of a product. To apply these processes, a high level of skills and technical knowledge is needed. So, it becomes a critical factor in attracting stakeholder to a circular system in production to adopt it in this type of process. 
Table 1. Factor affecting circular for each observed unit.

\begin{tabular}{|c|c|c|c|c|}
\hline Key Factors & Unit 1 & Unit 2 & Unit 3 & Unit 4 \\
\hline Product redesign & & & $\begin{array}{l}\text { Increase in the } \\
\text { performance of the } \\
\text { new product }\end{array}$ & \\
\hline Process redesign & $\begin{array}{l}\text { a customized waste } \\
\text { collection and } \\
\text { management process } \\
\text { for the customer }\end{array}$ & $\begin{array}{l}\text { a business model that } \\
\text { focuses on reusing } \\
\text { depleted electronics in } \\
\text { the secondary market }\end{array}$ & & $\begin{array}{l}\text { Selection of } \\
\text { products based on } \\
\text { the level of data } \\
\text { security contained } \\
\text { in the E-Waste }\end{array}$ \\
\hline $\begin{array}{l}\text { Business model } \\
\text { innovation }\end{array}$ & $\begin{array}{l}\text { The new way to sell } \\
\text { a product }\end{array}$ & $\begin{array}{l}\text { Nex level called: } \\
\text { "upcycling." } \\
\text { Standard of } \\
\text { certification to control } \\
\text { and manage } \\
\text { the process }\end{array}$ & $\begin{array}{l}\text { a new model focused on } \\
\text { innovation (patented) }\end{array}$ & $\begin{array}{l}\text { Business focused } \\
\text { on diverted waste } \\
\text { reuse: repair and } \\
\text { renovation of } \\
\text { recycled devices }\end{array}$ \\
\hline $\begin{array}{l}\text { Organizational } \\
\text { innovation }\end{array}$ & $\begin{array}{l}\text { Use of company } \\
\text { certification standards }\end{array}$ & $\begin{array}{l}\text { Focus on reuse and } \\
\text { recycling } \\
\text { Best Governance prize } \\
\text { Best world } \\
\text { honorees prize }\end{array}$ & $\begin{array}{l}\text { Awards and Use of } \\
\text { company certification } \\
\text { standards } \\
\text { Best world } \\
\text { honorees prize }\end{array}$ & $\begin{array}{l}\text { Awards and Use of } \\
\text { company } \\
\text { certification } \\
\text { standards }\end{array}$ \\
\hline $\begin{array}{l}\text { Waste Reduction } \\
\text { or reuse }\end{array}$ & Best environment prize & Best environment prize & $\begin{array}{l}\text { Recycling of exhausted } \\
\text { tires, } \\
\text { meditating a pelletizing pro } \\
\text { that reaches } 100 \% \text { of the } \\
\text { reuse of the waste } \\
\text { product. Best } \\
\text { environment prize }\end{array}$ & $\begin{array}{l}\text { cess } \\
\text { N/A }\end{array}$ \\
\hline Regulation & $\begin{array}{l}\text { High-level and } \\
\text { customized services to } \\
\text { overcome the } \\
\text { responsibilities of } \\
\text { sensitive data. }\end{array}$ & $\begin{array}{l}\text { There are few } \\
\text { regulations, } \\
\text { ordinances, } \\
\text { or incentives around } \\
\text { reuse. The enterprises } \\
\text { foster this changing }\end{array}$ & $\mathrm{N} / \mathrm{A}$ & $\mathrm{N} / \mathrm{A}$ \\
\hline $\begin{array}{l}\text { Inter-organizational } \\
\text { symbiosis }\end{array}$ & $\begin{array}{l}\text { The firm customizes } \\
\text { solutions for } \\
\text { the customer }\end{array}$ & $\begin{array}{l}\text { Greater awareness } \\
\text { about the risks of } \\
\text { improper destruction } \\
\text { or disposal of e-waste. }\end{array}$ & $\begin{array}{l}\text { Palletizing allows for } \\
\text { easy re-use of the } \\
\text { product. } \\
\text { Need to have many } \\
\text { customers } \\
\text { Toll collection constraint } \\
\text { equal to } 1000 \text { miles. }\end{array}$ & $\mathrm{N} / \mathrm{A}$ \\
\hline $\begin{array}{l}\text { Consumer } \\
\text { behavior }\end{array}$ & $\begin{array}{l}\text { High service of } \\
\text { customer satisfaction. } \\
\text { Web activity to sell the } \\
\text { product. }\end{array}$ & $\mathrm{N} / \mathrm{A}$ & $\mathrm{N} / \mathrm{A}$ & $\begin{array}{l}\text { Stimuli by } \\
\text { combining } \\
\text { recycling for work }\end{array}$ \\
\hline $\begin{array}{l}\text { Financial Stimuli } \\
\text { and Fiscal Stimuli }\end{array}$ & $\mathrm{N} / \mathrm{A}$ & $\mathrm{N} / \mathrm{A}$ & $\begin{array}{l}\text { The enterprise attracted } \\
\text { individual angel } \\
\text { investors and } \\
\text { institutional funding }\end{array}$ & $\mathrm{N} / \mathrm{A}$ \\
\hline Circularity & $\begin{array}{l}\text { SOCIAL RECYCLING } \\
\text { The activity is oriented } \\
\text { to sustainability and } \\
\text { recycling }\end{array}$ & $\begin{array}{l}\text { REGENERATIVE } \\
\text { The enterprise changes } \\
\text { the way to manage } \\
\text { waste, fostering reuse } \\
\text { with the re-generation } \\
\text { of a product in the } \\
\text { secondary market }\end{array}$ & $\begin{array}{l}\text { REGENERATIVE } \\
\text { High exploitation of } \\
\text { waste } \\
\text { High innovation } \\
\text { Many reference markets } \\
\text { (e.g., from belts, pipes, } \\
\text { building materials to } \\
\text { clothing, etc.) }\end{array}$ & $\begin{array}{l}\text { SOCIAL } \\
\text { RECYCLING } \\
\text { The activity is } \\
\text { oriented to recycle } \\
\text { and to social } \\
\text { welfare recycle }\end{array}$ \\
\hline $\begin{array}{l}\text { Total score for B } \\
\text { Corp }\end{array}$ & 111 & 145 & 118 & 95 \\
\hline
\end{tabular}

"Organizational-innovation" is the pillar for the diffusion of the best practices within the enterprises and to activate stakeholders. In Unit 2 and 3, the stakeholder commitment is activated by the certification standard, which is focused on reuse or recycling. Notably, the recognition of the company's high performance takes place through the delivery of Honorees for each impact area. Therefore, the awards for best B Corp can activate opportunities for contact with investors, policymakers, or other stakeholders.

All the mentioned factors have an impact on "waste reduction or reuse." The B Corp emphasizes the continuous improvement approach with the standard level, stimulating the increase in the performance of the process (and in the product redesign). Also, the prizes "Best For 
Environment", "Best for Governance", and "Best for Community" (obtained from the Units, see Table 1) contribute to the company's internal involvement in the achievement of the of BCorp principles. Consequently, the enterprises can support image consolidation and also the trust in the enterprises through second-party stakeholders.

Indeed, the "Regulation" imposes rules and conditions, often binding, for the waste treatment and/or the disposal. They also affect waste management or their potential reuse in the industry with a high level of bureaucracy that limits the possibility to intervene or change the value chain.

In Units 1,2, and 4, the criticalities in the management of e-waste and in the reuse is overcome with strict certification systems. Under Unit 3, the "users" are obliged to follow a disposal process.

"Fiscal and Financial"(g), such as organizational innovation, are the background to the inter-organization symbiosis. It creates the opportunity for cooperation for the technological or funding of new entities. The Inter-organizational symbiosis attracts the above factors. The model is stressed by the whole industry in which the firms become catalysts for the activation of a new loop.

In regards to the "Customer behavior" factor, original results emerge. In the rankings assigned at the time of certification, the companies have not achieved any score, except for Unit 2, which stands out for the Health and wellness improvement and serving in need populations. The enterprises have internal tools to increase customer satisfaction or to stimulate customer behavior, nevertheless the customer does not seem to be a central factor in the policy of this typology of enterprises.

The focus is oriented on the "users behaviour" which represents the real reference point of this mechanism of inter-organizational exchange. In particular, two possible scenarios emerge from the analysis that describes the circular business approach and the stakeholder's role in the activation of such a mechanism.

In the first scenario, besides the factors of sustainability and recycle, another relevant element emerges about the social aspect in activities performed by the companies. For such a reason, this scenario is defined as "social recycling", that is the context in which the companies, though oriented towards their recycling policies, can activate circular mechanisms considering the reuse of waste, with a substantial social impact, which is reachable through the involvement of primary and secondary stakeholders. The intervention of a Foundation or the involvement of an entire community realized in the first and the fourth units, respectively, offers the possibility to take action on the capacity to produce new occupations through the action of "social involvement of individuals" or supporting solid-environmental sustainability. Within this first scenario, the high personalization of the services offered to clients allows the companies to activate organizational symbioses to facilitate the exchanges of product-waste. At the same time, this allows bypassing the limitations imposed by the regulation, also thanks to the adoption of strict standards, allowing them, in this case, to find a solution to the criticalities in the enforcement of the norms on privacy for the management of sensitive data contained in the e-waste.

The certifications represent a stimulus from the bottom, in a bottom-up logic, in line with the literature (see, for example, [66-71]), for more sustainable manufacture of products and in accordance with the circular economy principles.

Moreover, in this scenario, the "social aspect" of the B Corp enterprises represents the critical factor for the switch toward a circular economy, constituting the spring that allows the activation of a network of stakeholders in pursuing the aims of certification and the principles of the circular economy. The second scenario can be defined as "highly regenerative." In it, the principal actors are involved in the regeneration of waste through the extension of the products' life cycle or the "high valorization", that is through the non-obvious reuse involving high skills and/or technological innovation and the reactivation or valorization of waste as first or second raw materials. In such a context, the new behavior is required in the management of waste. In Unit 2, this is obtained through the reactivation of single components so that regenerating and re-collocation on the secondary market is equal to $85 \%$ of the recycled products, which in unit 3 raises $100 \%$ of the waste, thanks to its 
re-collocation in many reference markets thanks to its high degree of innovation in the process and specialization of human resources.

This scenario evokes a multi-stakeholder perspective. It is represented by highly qualified suppliers (i.e., the reference markets are in unit 2 Technology, Medical, Return-to-Vendor, Manufacturers, Schools/Universities, Government/Defense, Professional Services, Non-Profit Organizations) with a high degree of competences and specializations. The market they refer to as tires is fragmented and anonymous. Here, "Nobody knows anything about it"(Unit 3). At the same time, it is characterized by inter-organizational symbioses. Stakeholders are engaged in the activation of circular processes of waste recycling for the exploitation of scrap or to attract new resources (institutional or individual). On the whole, the cases analyzed are characterized by multiple stakeholder perspectives and a bottom-up approach, leading to the adoption of circular economy principles. a more symbiotic perspective, supported by the B Corp certification, is also considered, where the role of the community and the engagement in a global movement leads to a change towards a more virtuous behavior on the part of all the individuals and companies involved in the pursuit of economic and social growth.

On the whole, the cases analyzed are characterized by multiple stakeholder perspectives and a bottom-up approach, leading to the adoption of circular economy principles. A more symbiotic perspective, supported by the B Corp certification, is also considered where the role of the community and the engagement in a global movement leads to a change towards a more virtuous behavior on the part of all the individuals and companies involved in the pursuit of economic and social growth.

\section{Conclusions}

The critical revision of the potential of the B Corp certification crossed with the circular economy principles offers the opportunity to depict dynamic multiple stakeholder viewpoints.

The studies on the use of certifications (e.g., [66,72-75] and more in general on the stakeholder e.g., $[2,4,76,77])$ to support the transition to a circular economy demonstrates the wide nature of the subject and its huge contemporary impact. Moreover, they highlight the existence of unexplored aspects concerning the objectives to achieve and to better understand the level of awareness of the business companies and the consumers and to identify the most suitable forms for the realization of the circular economy.

From the factors observed, different stakeholders operating in the international framework can activate circular economy paths through the adoption of the B Corp certification.

The analysis highlights two possible scenarios in which a circular economy is activated, taking into account the stakeholders' perspective. a "social recycling" scenario contributes to the development of business recycling policies, wherein the social aspect represents a critical factor for the switch toward a circular economy. While a "Highly Regenerative" scenario stresses the extension of the products' life cycle or the "high valorization" of waste in second raw material.

On the whole, the "users behavior" represents the critical aspect that allows the effective transition to the new framework, stimulating the loop cycle of reuse.

The qualitative approach of this study is largely based on a transparent document revision process. While it could be considered a limitation, it reduces the uncertainties and discretion of the researcher in the analysis or interpretation of a phenomenon.

The selection of the case studies has been done within the B Corp certified businesses. A precise "recycling service \& waste management research principle was adopted to identify the organizations with a specific attitude towards the adoption of circular economy practices".

The link between B Corp certification, the application of the circular economy, and the stakeholder role indeed requires further investigation.

The future step of our research will focus on the ranking system assigned by the B Corp certification system to understand the switching moment that allows considering "circular" as an enterprise. Further work is needed to collect data on B Corp assessment models. This could be done 
by systematic analysis of the different sectors covered by the B Corp certification system and the level of stakeholder participation. In this way, the certification metrics (provided by the ranking) can be adapted to the factors and principles of the circular economy. This procedure could help to reveal the role of certification as a lever of sustainability, highlighting the influence of stakeholders in this shake-up.

Author Contributions: Conceptualization, S.P., A.C.; methodology, S.P., S.R.S.C.; formal analysis, S.P., A.C., and E.M.M.; writing — original draft preparation, S.P., E.M.; validation, A.C., S.R.S.C.; writing—review and editing, A.C., S.R.S.C.; supervision, E.M.M.

Funding: This research received no external funding.

Conflicts of Interest: The authors declare no conflicts of interest.

\section{References}

1. Brandenburg, M.; Govindan, K.; Sarkis, J.; Seuring, S. Quantitative models for sustainable supply chain management: Developments and directions. Eur. J. Oper. Res. 2014, 233, 299-312. [CrossRef]

2. Andersen, M.S. An introductory note on the environmental economics of the circular economy. Sustain. Sci. 2006, 2, 133-140. [CrossRef]

3. European Commision. An EU Action Plan for the Circular Economy; European Commision: Luxembourg, 2015; Volume 614, p. 21.

4. Viveros, H. Managerial perceptions of stakeholder salience in mining. Extr. Ind. Soc. 2016, 3, 987-996. [CrossRef]

5. Ruggieri, A.; Braccini, A.M.; Poponi, S.; Mosconi, E.M. a meta-model of inter-organisational cooperation for the transition to a circular economy. Sustainability 2016, 8, 1153. [CrossRef]

6. Sakao, T.; Panshef, V.; Dörsam, E. Addressing uncertainty of PSS for value-chain oriented service devleopment. In Intorduction to Product/Service-System Design; Sakao, T., Lindahl, M., Eds.; Springer: London, UK, 2009; pp. 137-157.

7. Iung, B.; Levrat, E. Advanced Maintenance Services for Promoting Sustainability. Procedia CIRP 2014, 22, 15-22. [CrossRef]

8. Lieder, M.; Rashid, A. Towards circular economy implementation: a comprehensive review in context of manufacturing industry. J. Clean. Prod. 2015, 115, 36-51. [CrossRef]

9. Sousa-Zomer, T.T.; Magalhães, L.; Zancul, E.; Campos, L.M.S.S.; Cauchick-Miguel, P.A. Cleaner production as an antecedent for circular economy paradigm shift at the micro-level: Evidence from a home appliance manufacturer. J. Clean. Prod. 2018, 185, 740-748. [CrossRef]

10. Merli, R.; Preziosi, M.; Acampora, A. How do scholars approach the circular economy? A systematic literature review. J. Clean. Prod. 2018, 178, 703-722. [CrossRef]

11. B-Corporations Why B Corps Matter I B Corporation. Available online: https://www.bcorporation.net/ what-are-b-corps/why-b-corps-matter (accessed on 18 July 2017).

12. Wilburn, K.; Wilburn, R. The double bottom line: Profit and social benefit. Bus. Horiz. 2014, 57, 11-20. [CrossRef]

13. Ruggieri, A.; Mosconi, E.M.; Poponi, S. The B Corp certification as a standard of the entrepreneurial pathway towards the circular economy perspective. In Proceedings of the XXVIII National Congress of Commodity Sciences, Firenze, Italy, 21-23 February 2018.

14. Liu, D.; Li, H.; Wang, W.; Dong, Y. Constructivism scenario evolutionary analysis of zero emission regional planning: a case of Qaidam Circular Economy Pilot Area in China. Int. J. Prod. Econ. 2012, 140, 341-356. [CrossRef]

15. Ma, S.; Wen, Z.; Chen, J.; Wen, Z. Mode of circular economy in China's iron and steel industry: a case study in Wu'an city. J. Clean. Prod. 2014, 64, 505-512. [CrossRef]

16. Ghisellini, P.; Cialani, C.; Ulgiati, S. a review on circular economy: The expected transition to a balanced interplay of environmental and economic systems. J. Clean. Prod. 2014, 114, 11-32. [CrossRef]

17. Blomsma, F.; Brennan, G. The Emergence of Circular Economy a New Framing Around Prolonging Resource Productivity. Res. Anal. 2017, 21, 603-614. [CrossRef] 
18. Romero, D.; Rossi, M. Towards Circular Lean Product-Service Systems. Procedia CIRP 2017, 64, 13-18. [CrossRef]

19. Fieschi, M.; Pretato, U. Role of compostable tableware in food service and waste management. A life cycle assessment study. Waste Manag. 2018, 73, 14-25. [CrossRef] [PubMed]

20. Marques, A.; Guedes, G.; Ferreira, F. Leather wastes in the Portuguese footwear industry: New framework according design principles and circular economy. Procedia Eng. 2017, 200, 303-308. [CrossRef]

21. Niero, M.; Schmidt, X.C.; Rivera, X.C.S. The Role of Life Cycle Sustainability Assessment in the Implementation of Circular Economy Principles in Organizations. Procedia CIRP 2018, 69, 793-798. [CrossRef]

22. Lecerf, L.; De, L.; Skinner, A.; De, S.; Kunz, S.; De, K. Moving towards a circular economy with EMAS; Publications Office of the European Union: Luxembourg, 2017.

23. Brundtland, G.H. Our Common Future. (Oxford Paperbacks); Oxford University Press: Oxford, UK, 1987; 400p.

24. Svendsen, G.T. Environmental Reviews and Case Studies: From a Brown to a Green Economy: How Should Green Industries Be Promoted? Environ. Pract. 2013, 15, 72-78. [CrossRef]

25. Zengwei, Y.; Jun, B.; Yuichi, M. The circular economy: a new development strategy in China. J. Ind. Ecol. 2006, 10, 4-8.

26. Mathews, J.A. Naturalizing capitalism: The next Great Transformation. Futures 2011, 43, 868-879. [CrossRef]

27. Geng, Y.; Fu, J.; Sarkis, J.; Xue, B. Towards a national circular economy indicator system in China: An evaluation and critical analysis. J. Clean. Prod. 2012, 23, 216-224. [CrossRef]

28. Clark, G.; Kosoris, J.; Hong, L.N.; Crul, M. Design for sustainability: Current trends in sustainable product design and development. Sustainability 2009, 1, 409-424. [CrossRef]

29. Behrisch, J.; Ramirez, M.; Giurco, D. Representation of Ecodesign Practice: International Comparison of Industrial Design Consultancies. Sustainability 2011, 3, 1778-1791. [CrossRef]

30. Pigosso, D.C.A.; Ferraz, M.; Teixeira, C.E.; Rozenfeld, H. The deployment of product-related environmental legislation into product requirements. Sustainability 2016, 8, 332. [CrossRef]

31. Brax, S. a Manufacturer Becoming Service Provider-Challenges and a Paradox. Manag. Serv. Qual. 2005, 15, 142-155. [CrossRef]

32. Beuren, F.H.; Gomes Ferreira, M.G.; Cauchick Miguel, P.A. Product-service systems: a literature review on integrated products and services. J. Clean. Prod. 2013, 47, 222-231. [CrossRef]

33. Cook, M.B.; Bhamra, T.A.; Lemon, M. The transfer and application of Product Service Systems: From academia to UK manufacturing firms. J. Clean. Prod. 2006, 14, 1455-1465. [CrossRef]

34. Schulte, U.G. New business models for a radical change in resource efficiency. Environ. Innov. Soc. Trans. 2013, 9, 43-47. [CrossRef]

35. Scheepens, A.E.; Vogtländer, J.G.; Brezet, J.C. Two life cycle assessment (LCA) based methods to analyse and design complex (regional) circular economy systems. Case: Making water tourism more sustainable. J. Clean. Prod. 2016, 114, 257-268. [CrossRef]

36. Ellen Macarthur Foundation. Towards the Circular Economy: Accelerating the Scale-Up Across Global Supply Chains; Ellen Macarthur Foundation: Cowes, UK, 2014.

37. Scheel, C. Beyond Sustainability. Transforming industrial zero-valued residues into increasing economic returns. J. Clean. Prod. 2016, 131, 376-386. [CrossRef]

38. Baines, T.S.; Lightfoot, H.W.; Evans, S.; Neely, A.; Greenough, R.; Peppard, J.; Roy, R.; Shehab, E.; Braganza, A.; Tiwari, A.; et al. State-of-the-art in product-service systems. Proc. Inst. Mech. Eng. Part B J. Eng. Manuf. 2007, 221, 1543-1552. [CrossRef]

39. Zhao, Y.; Zang, L.; Li, Z.; Qin, J. Discussion on the Model of Mining Circular Economy. Energy Procedia 2012, 16, 438-443. [CrossRef]

40. Park, J.Y.; Chertow, M.R. Establishing and testing the "reuse potential" indicator for managing wastes as resources. J. Environ. Manag. 2014, 137, 45-53. [CrossRef] [PubMed]

41. Sevigné-Itoiz, E.; Gasol, C.M.; Rieradevall, J.; Gabarrell, X. Environmental consequences of recycling aluminum old scrap in a global market. Resour. Conserv. Recycl. 2014, 89, 94-103. [CrossRef]

42. Matus, K.J.M.; Xiao, X.; Zimmerman, J.B. Green chemistry and green engineering in China: drivers, policies and barriers to innovation. J. Clean. Prod. 2012, 32, 193-203. [CrossRef]

43. Winkler, H. Closed-loop production systems-A sustainable supply chain approach. CIRP J. Manuf. Sci. Technol. 2011, 4, 243-246. [CrossRef] 
44. Riding, M.J.; Herbert, B.M.J.J.; Ricketts, L.; Dodd, I.; Ostle, N.; Semple, K.T. Harmonising conflicts between science, regulation, perception and environmental impact: The case of soil conditioners from bioenergy. Environ. Int. 2015, 75, 52-67. [CrossRef] [PubMed]

45. Xue, B.; Chen, X.P.; Geng, Y.; Guo, X.J.; Lu, C.P.; Zhang, Z.L.; Lu, C.Y. Survey of officials' awareness on circular economy development in China: Based on municipal and county level. Resour. Conserv. Recycl. 2010, 54, 1296-1302. [CrossRef]

46. Scharff, H. Landfill reduction experience in The Netherlands. Waste Manag. (New York) 2014, 34, $2218-2224$. [CrossRef] [PubMed]

47. Zhu, Q.; Geng, Y.; Lai, K. Circular economy practices among Chinese manufacturers varying in environmental-oriented supply chain cooperation and the performance implications. J. Environ. Manag. 2010, 91, 1324-1331. [CrossRef] [PubMed]

48. Ying, J.; Li-jun, Z. Study on Green Supply Chain Management Based on Circular Economy. Phys. Procedia 2012, 25, 1682-1688. [CrossRef]

49. Kuznetsova, E.; Zio, E.; Farel, R. a methodological framework for Eco-Industrial Park design and optimization. J. Clean. Prod. 2015, 126, 308-324. [CrossRef]

50. Jiao, W.; Boons, F. Toward a research agenda for policy intervention and facilitation to enhance industrial symbiosis based on a comprehensive literature review. J. Clean. Prod. 2014, 67, 14-25. [CrossRef]

51. Wen, Z;; Meng, X. Quantitative assessment of industrial symbiosis for the promotion of circular economy: A case study of the printed circuit boards industry in China's Suzhou New District. J. Clean. Prod. 2014, 90, 211-219. [CrossRef]

52. Yang, S.; Feng, N. a case study of industrial symbiosis: Nanning Sugar Co., Ltd. in China. Resour. Conserv. Recycl. 2008, 52, 813-820. [CrossRef]

53. Yu, F.; Han, F.; Cui, Z. Evolution of industrial symbiosis in an eco-industrial park in China. J. Clean. Prod. 2015, 87, 339-347. [CrossRef]

54. Adamides, E.D.; Yannis, M. Industrial ecosystems as technological niches. J. Clean. Prod. 2009, 17, $172-180$. [CrossRef]

55. Cohen, S.I. Urban growth and circular flow in a SAM-framework: The case of The Netherlands. Soc.-Econ. Plan. Sciences 1996, 30, 1-14. [CrossRef]

56. Yu, C.; de Jong, M.; Dijkema, G.P.J. Process analysis of eco-industrial park development-The case of Tianjin, China. J. Clean. Prod. 2014, 64, 464-477. [CrossRef]

57. Bain, A.; Shenoy, M.; Ashton, W.; Chertow, M. Industrial symbiosis and waste recovery in an Indian industrial area. Resour. Conserv. Recycl. 2010, 54, 1278-1287. [CrossRef]

58. Yang, Z.; Wang, W. The research on pricing strategy for perishable high-tech products based on circular economy. Energy Procedia 2011, 5, 1842-1846.

59. Mont, O.; Tukker, A. Product-Service Systems: Reviewing Achievements and Refining the Research Agenda. J. Clean. Prod. 2006, 14, 1451-1454. [CrossRef]

60. Liu, Y.; Bai, Y. An exploration of firms' awareness and behavior of developing circular economy: An empirical research in China. Resour. Conserv. Recycl. 2014, 87, 145-152. [CrossRef]

61. Leimeister, J.M.; Glauner, C. Hybride Produkte e Enordunung und Her-ausforderungen für die Wirtschaftsinformatik. Wirtschaftsinformatik 2008, 50, 248-251. [CrossRef]

62. B Lab. GIIRS Funds I B Analytics. Available online: http://b-analytics.net/giirs-funds (accessed on 21 January 2019).

63. Yin, R.K. Case Study Research: Design and Methods; Sage Publishing: Thousand Oaks, CA, USA, 1994.

64. Yin, R.K. Case Study Research: Design and Methods, 4th ed.; Conneley, S., Ed.; Sage Publicaitons: Thousand Oaks, CA, USA, 2009.

65. Silverman, D. Interpreting Qualitative Data: a Guide to the Principles of Qualitative Research; Sage Publications Ltd.: Thousand Oaks, CA, USA, 2011.

66. Llorach-Massana, P.; Farreny, R.; Oliver-Sol, J. Are Cradle to Cradle certified products environmentally preferable? Analysis from an LCA approach'. J. Clean. Prod. 2016, 113, 715-716. [CrossRef]

67. Niero, M.; Hauschild, M.Z. Closing the Loop for Packaging: Finding a Framework to Operationalize Circular Economy Strategies. Procedia CIRP 2017, 61, 685-690. [CrossRef]

68. Sousa-Zomer, T.T.; Magalhães, L.; Zancul, E.; Cauchick-Miguel, P.A. Lifecycle Management of Product-service Systems: a Preliminary Investigation of a White Goods Manufacturer. Procedia CIRP 2017, 64, 31-36. [CrossRef] 
69. Pomponi, F.; Moncaster, A. Circular economy for the built environment: a research framework. J. Clean. Prod. 2017, 143, 710-718. [CrossRef]

70. Zeller, V.; Towa, E.; Degrez, M.; Achten, W.M.J. Integration of Waste Supply and Use Data into Regional Footprints: Case Study on the Generation and Use of Waste from Consumption and Production Activities in Brussels. Procedia CIRP 2018, 69, 100-105. [CrossRef]

71. Merli, R.; Preziosi, M. The EMAS impasse: Factors in fluencing Italian organizations to withdraw or renew the registration. J. Clean. Prod. 2018, 172, 4532-4543. [CrossRef]

72. Daddi, T.; Iraldo, F.; Frey, M.; Gallo, P.; Gianfrate, V. Regional policies and eco-industrial development: The voluntary environmental certification scheme of the eco-industrial parks in Tuscany (Italy). J. Clean. Prod. 2016, 114, 62-70. [CrossRef]

73. Merli, R.; Lucchetti, M.C.; Preziosi, M.; Arcese, G. Causes of Eco-Management and Audit Scheme (EMAS) stagnation and enabling measures to stimulate new registrations: Characterization of public administrations and private-owned organizations. J. Clean. Prod. 2018, 190, 137-148. [CrossRef]

74. Zhu, Q.; Cordeiro, J.; Sarkis, J. Institutional pressures, dynamic capabilities and environmental management systems: Investigating the ISO 9000-Environmental management system implementation linkage. J. Environ. Manage. 2013, 114, 232-242. [CrossRef] [PubMed]

75. Grimaud, G.; Perry, N.; Laratte, B. Development of an Evaluation Tool for Engineering Sustainable Recycling Pathways. Procedia CIRP 2018, 69, 781-786. [CrossRef]

76. Leipold, S.; Petit-Boix, A. The circular economy and the bio-based sector-Perspectives of European and German stakeholders. J. Clean. Prod. 2018, 201, 1125-1137. [CrossRef]

77. Oldfield, T.L.; White, E.; Holden, N.M. The implications of stakeholder perspective for LCA of wasted food and green waste. J. Clean. Prod. 2018, 170, 1554-1564. [CrossRef]

(C) 2019 by the authors. Licensee MDPI, Basel, Switzerland. This article is an open access article distributed under the terms and conditions of the Creative Commons Attribution (CC BY) license (http:/ / creativecommons.org/licenses/by/4.0/). 